Situs Jurnal : http://ejurnal.stiepancasetia.ac.id/index.php/jieb

Jilid 4 Nomor 3 November 2018

Hal 361 - 376

\title{
TATA KELOLA BELANJA MODAL DAN BELANJA PEGAWAI UNTUK PENINGKATAN PERTUMBUHAN EKONOMI DAERAH DAN INDEKS PEMBANGUNAN MANUSIA DI KABUPATEN HULU SUNGAI TENGAH TAHUN 2010 - 2016
}

\section{Mohamad Fajerin*}

Abstract: This article describes the results of governance research on capital expenditure (BM) and personnel expenditure (BG) in Hulu Sungai Tengah (HST) district. BM direct test results have a significant positive effect on regional economic growth in HST Regency 20102016, path coefficient of 0.310 , significance level $<5 \%$, BM has a significant positive effect on economic growth, with a path coefficient of 0.468 significance level $<5 \%$, BM has a positive effect significant to HDI, path coefficient 0.301 with a significance level of $<5 \%$, BG has a positive and significant effect on HDI, path coefficient 0.582 significance level $<5 \%$; Regional economic growth has a significant positive effect on HDI, path coefficient 0.556 significance level $<5 \%$. Indirect testing of regional economic growth mediates the relationship of BM with shown path coefficients of 0.333 , significance level of $<5 \%$, regional economic growth mediates the relationship of personnel expenditure with HDI indicated path coefficient 0.414 significance level $<5 \%$.

Keywords: capital expenditure, employee expenditure, economic growth, HDI

Abstrak: Artikel ini mendeskripsikan hasil penelitian tata kelola belanja modal (BM) dan belanja pegawai (BG) di kabupateh Hulu Sungai Tengah (HST). Hasil pengujian langsung BM berpengaruh positif signifikan terhadap pertumbuhan ekonomi daerah di Kabupaten HST 2010-2016, koefisien jalur sebesar 0,310, taraf signifikansi $<5 \%$, BM berpengaruh positif signifikan terhadap pertumbuhan ekonomi, dengan koefesien jalur 0,468 taraf signifikansi $<5 \%$, BM berpengaruh positif signifikan terhadap IPM , koefesien jalur 0,301 dengan taraf signifikansi $<5 \%$, BG berpengaruh positif dan signifikan terhadap IPM, koefesien jalur 0,582 taraf signifikansi $<5 \%$; Pertumbuhan ekonomi daerah berpengaruh positif signifikan terhadap IPM, koefesien jalur 0,556 taraf signifikansi < 5\%. Pengujian tidak langsung pertumbuhan ekonomi daerah memediasi hubungan BM dengan ditunjukkan koefesien jalur 0,333 , taraf signifikansi $<5 \%$, pertumbuhan ekonomi daerah memediasi hubungan belanja pegawai dengan IPM ditunjukkan koefesien jalur 0,414 taraf signifikansi $<5 \%$.

Kata kunci : Belanja modal, Belanja pegawai, Pertumbuhan ekonomi, IPM

\section{Latar Belakang}

Kemampuan daerah dalam memanajemen dan mengelola sumber daya yang dimiliki dapat dijadikan sebagai sumber kekayaan bagi daerah. Pengelolaan sumberdaya daerah pada antara lain bidang ekonomi, pertanian, seni budaya dapat menciptakan lapangan kerja baru dan dapat merangsang perkembangan kegiatan ekonomi, dan dapat menambah pendapatan bagi daerah. Daerah otonom dapat memiliki pendapatan yang digunakan untuk membiayai 
penyelenggaraan urusan rumah tangganya secara efektif dan efesien dengan memberikan pelayanan dan pembangunan. Tujuan pemberian otonomi daerah adalah untuk lebih meningkatkan kesejahteraan dan pelayanan kepada masyarakat, pemgembangan kehidupan berdemokrasi, keadilan, pemerataan, dan pemeliharaan hubungan yang serasi antara pusat dan daerah serta antar daerah (Sidik, et al, 2002 : 54). Visi otonomi dari sudut pandang ekonomi mempunyai tujuan akhir untuk membawa masyarakat ketingkat kesejahteraan yang lebih tinggi dari waktu ke waktu (Syaukani, et al, 2005).

Pelaksanaan otonomi daerah memberikan kewenangan yang begitu luas bagi daerah. Hal ini di satu sisi merupakan berkat, namun disisi lain sekaligus merupakan beban yang pada saatnya nanti akan menuntut kesiapan daerah untuk dapat melaksanakannya. Dengan kewenangan yang diberikan oleh pemerintah pusat, maka beberapa aspek harus dipersiapkan, antara lain sumber daya manusia, sumber daya keuangan, sarana dan prasarana, serta organisasi dan manajemennya.

Berkaitan dengan hal itu, manajemen melalui strategi alokasi belanja daerah memainkan peranan yang tidak kalah penting guna meningkatkan penerimaan daerah. Dalam upaya untuk meningkatkan kontribusi publik terhadap penerimaan daerah, alokasi belanja modal hendaknya lebih ditingkatkan. Belanja modal yang dilakukan oleh pemerintah daerah diantaranya pembangunan dan perbaikan sektor pendidikan, kesehatan, transportasi, sehingga masyarakat juga menikmati manfaat dari pembangunan daerah. Oleh karena itu, anggaran belanja daerah akan tidak logis jika proporsi anggarannya lebih banyak untuk belanja rutin (Abimanyu, 2005). Semakin banyak pendapatan yang dihasilkan oleh daerah, baik dari dana alokasi umum (DAU) maupun pendapatan asli daerah sendiri, daerah akan mampu memenuhi dan membiayai semua keperluan yang diharapkan oleh masyarakat.

Pergeseran komposisi belanja merupakan upaya logis yang dilakukan pemerintah daerah setempat dalam rangka meningkatkan tingkat kepercayaan publik. Pergeseran ini ditujukan untuk peningkatan investasi modal dalam bentuk asset tetap, yakni peralatan, bangunan, infrastruktur, dan harta tetap lainnya. Semakin tinggi tingkat investasi modal diharapkan mampu meningkatkan kualitas layanan publik dan pada gilirannya mampu meningkatkan tingkat partisipasi (kontribusi) publik terhadap pembangunan.

Anggaran belanja modal ini didasarkan pada kebutuhan daerah akan sarana dan prasarana, baik untuk kelancaran pelaksanaan tugas pemerintah maupun untuk fasilitas publik. Oleh karena itu, dalam upaya meningkatkan kualitas pelayanan publik, pemerintah daerah seharusnya mengubah komposisi belanjanya.Selama ini belanja daerah lebih banyak digunakan untuk belanja rutin yang relatif kurang produktif. Saragih (2003) menyatakan bahwa pemanfaatan belanja hendaknya dialokasikan untuk hal-hal produktif, misalnya untuk melakukan aktivitas pembangunan.

Menurut Adam Smit dalam penelitian Dahar (2012), selain berpengaruh terhadap pertumbuhan ekonomi daerah belanja modal juga dapat mempengaruhi indek pembangunan manusia. Kebijakan pelaksanaan otonomi daerah dan desentralisasi fiscal didasarkan pada pertimbangan bahwa daerahlah yang lebih mengetahui kebutuhan dan standar pelayanan bagi masyarakat di daerahnya, sehingga pemberian otonomi daerah diharapkan dapat memacu peningkatan kesejahteraan masyarakat di daerah melalui peningkatan pertumbuhan ekonomi.

Perbaikan pengalokasian dana untuk belanja modal selain belanja rutin ikut menopang perbaikan kesejahteraan. Menurut United Nation Development Programme (UNDP, 1996) hubungan antara pertumbuhan ekonomi dan pembangunan ekonomi bersifat timbal balik, artinya apabila terdapat pertumbuhan ekonomi maka akan mempengaruhi pebangunan manusianya.

Indeks pembangunan masyarakat (IPM) terdapat 3 indikator utama, yaitu indikator kesehatan, tingkat pendidikan dan indikator ekonomi. Pengukuran ini menggunakan tiga dimensi dasar yaitu lamanya hidup, pengetahuan, dan sumber hidup yang layak.Ketiga unsur 
tersebut tidak berdiri sendiri, melainkan saling mempengaruhi satu dengan yang lainnya. Selain juga dipengaruhi oleh faktor-faktor lain seperti ketersediaan kesempatan kerja, yang pada gilirannya ditentukan oleh banyak faktor, terutama pertumbuhan ekonomi, insfrastruktur dan kebijakan pemerintah.

Berdasarkan latar belakang permasalahan tersebut dapat diketahui bahwa pengelolaan anggaran belanja daerah sangat penting, khususnya terkait dengan alokasi belanja modal dan belanja pegawai idealnya untuk mencapai suatu keberhasilan dalam pertumbuhan ekonomi dan pembangunan manusia, porsi anggaran untuk belanja modal lebih tinggi daripada posisi belanja pegawai, karena belanja modal sangat terkait dengan pembangunan sarana dan prasarana yang mendukung kebutuhan dasar hidup seperti sekolah, pendidikan dan fasilitas ekonomi. Belanja modal merupakan aspek penting untuk terciptanya pertumbuhan ekonomi dan pembangunan manusia.

Hubungan antara dana alokasi umum, belanja modal dan kualitas pembangunan manusia mempunyai hubungan signifikan, dimana kualitas pembangunan manusia sangat tergantung dari adanya dana alokasi umum yang berasal dari pemerintah pusat dan juga besarnya belanja modal yang dianggarkan di daerah untuk menunjang pembangunan manusia.

Berdasarkan latar belakang permasalahan yang telah diuraikan akan dideskripsikan pada artikel hasil penelitian ini "Manajemen Pertumbuhan Ekonomi Daerah Dan Indeks Pembangunan Manusia Melalui Tata Kelola Belanja Modal Dan Belanja Pegawai Di Kabupaten Hulu Sungai Tengah Tahun 2010 - 2016".

\section{Kajian Literatur}

Tata kelola merupakan rangkaian proses, kebiasaan, kebijakan, aturan, dan institusi yang memengaruhi pengarahan, pengelolaan, serta pengontrolan suatu badan (Wikipedia bahasa Indonesia). Belanja modal adalah pengeluaran anggaran untuk perolehan aset tetap dan aset lainnya yang memberi manfaat lebih dari satu periode akuntansi. Belanja modal meliputi antara lain belanja tanah, belanja peralatan dan mesin, belanja modal gedung dan bangunan, belanja modal jalan, irigasi dan jaringan, belanja aset tetap lainnya, dan belanja aset lainnya (Halim, 2007 : 2010). Belanja modal dilakukan dalam rangka pembentukan modal yang sifatnya menambah aset tetap/inventaris yang memberikan manfaat lebih dari satu periode akuntansi, termasuk di dalamnya adalah pengeluaran untuk biaya pemeliharaan yang sifatnya mempertahankan atau menambah masa manfaat, meningkatkan kapasitas dan kualitas aset.

Menurut Peraturan Direktorat Jenderal Perbendaharaan Nomor PER-33/PB/2008 tentang Pedoman Penggunaan Akun Pendapatan, Belanja Pegawai, Belanja Barang dan Belanja Modal, belanja modal adalah pengeluaran yang dilakukan dalam rangka pembentukan modal yang sufatnya menambah aset tetap atau aset lainnhya yang memberikan manfaat lebih dari 1 (satu) periode akuntansi, termasuk didalamnya adalah pengeluaran untuk biaya pemeliharaan yang sifatnya mempertahankan atau menambah masa manfaat, meningkatkan kapasitas dan kualitas aset.

Menurut Halim (2004), belanja modal merupakan belanja yang manfaatnya melebihi satu tahun anggaran dan akan menambah aset atau kekayaan daerah serta akan menambah belanja yang bersifat rutin seperti biaya pemeliharaan. Berdasarkan Peraturan Menteri Dalam Negeri Nomor 22 tahun 2011 tentang Pedoman Penyusunan Anggaran Pendapatan dan Belanja Daerah Tahun Anggaran 2012, untuk belanja modal adalah sebagai berikut:

1. Penganggaran belanja modal, setelah dikurangi belanja pegawai pada kelompok belanja tidak langsung dan belanja wajib lainnya diprioritaskan sesuai Peraturan Presiden Nomor 5 Tahun 2010 tentang RPJMN Tahun 2010-2014.

2. Pengadaan kebutuhan barang milik daerah, menggunakan dasar perencanaan kebutuhan barang milik daerah sebagaimana diatur dalam Peraturan Menteri Dalam Negeri Noor 17 
Tahun 2007 tentang Pedoman Teknis Pengelolaan Barang Milik Daerah dan memperhatikan standar barang berdasarkan Peraturan Menteri Dalam Negeri Nomor 7 Tahun 2006 tentang Standarisasi Sarana dan Prasarana Kerja Pemerintah Daerah, sebagaimana diubah dengan Peraturan Menteri Dalam Negeri Nomor 11 Tahun 2007 tentang Perubahan Atas Peraturan Menteri Dalam Negeri Nomor 7 Tahun 2006. Berdasarkan Peraturan Direktorat Jenderal Perbendaharaan Nomor PER-33/PB/2008 tentang Pedoman Penggunaan Akun Pendapatan, Belanja Pegawai, Belanja Barang dan Belanja Modal sesuai dengan Bagan Akun Standar (BAS), suatu belanja dikategorikan sebagai belanja modal apabila :

a. Pengeluaran tersebut mengakibatkan adanya perolehan aset tetap atau aset lainnya yang menambah masa umur, manfaat dan kapasitas.

b. Pengeluaran tersebut melebihi batasan minimum kapitalisasi aset tetap atau aset lainnya yang telah ditetapkan pemerintah.

c. Perolehan aset tetap tersebut diniatkan bukan untuk dijual.Dalam Peraturan Direktorat Jenderal Perbendaharaan Nomor PER-33/PB/2008, juga menyebutkan bahwa belanja untuk pengeluaran-pengeluaran sesuadah perolehan aset lainnya yaitu belanja pemeliharaan yang dikapitalisasi dapat di masukkan ke dalam belanja modal dengan syarat antara lain : (1) pengeluaran tersebut mengakibatkan bertambahnya masa manfaat, kapasitas, kualitas dan volume aset yang telah dimiliki, dan (2) pengeluaran tersebut memenuhi batasan minimum nilai kapitalisasi aset tetap atau aset lainnya.

Belanja pegawai merupakan salah satu jenis pengeluaran pemerintah daerah yang tertuang dalam APBD.Setiap tahun pengeluaran ini selalu ada dalam APBD.Dalam APBD belanja pegawai termasuk dalam kategori belanja operasi, pemeliharaan sarana dan prasarana publik, yang merupakan pengeluaran pemerintah daerah yang berhubungan dengan aktivitas atau pelayanan publik. Belanja pegawai merupakan pengeluaran pemerintah daerah untuk orang/personal yang berhubungan dengan suatu aktivitas atau dengan kata lain merupakan belanja pegawai yang bersifat variabel. Belanja pegawai adalah semua pengeluaran yang digunakan untuk membiayai kompensasi dalam bentuk yang atau barang yang diberikan kepada pegawai daerah.

Penyusunan belanja pegawai dalam APBD diatur dalam Peraturan Menteri Dalam Negeri Nomor 22 tahun 2011 tentang Pedoman Penyusunan Anggaran Pendapatan dan Belanja Daerah Tahun Anggaran 2012, adalah sebagai berikut:

1. Besarnya penganggaran untuk gaji pokok dan tunjangan PNSD disesuaikan dengan hasil rekonsiliasi jumlah pegawai dan belanja pegawai dalam rangka perhitungan DAU Tahun Anggaran 2012 serta memperhitungkan rencana kenaikan gaji pokok dan tunjangan PNSD dan pemberian gaji ketiga belas.

2. Penganggaran belanja pegawai untuk kebutuhan pengangkatan Calon PNSD sesuai formasi pegawai tahun 2012.

3. Penganggaran belanja pegawai untuk kebutuhan kenaikan gaji berkala, kenaikan pangkat, tunjangan keluarga dan mutasi pegawai dengan memperhitungkan access yang besarnya maksimum 2,5\% (dua setengah persen) dari jumlah belanja pegawai untuk gaji pokok dan tunjangan.

4. Penyediaan dana penyelenggaraan asuransi kesehatan yang dibebankan pada APBD berpedoman pada Peraturan Pemerintah Nomor 28 Tahun 2003 tentang Subsidi dan Iuran Pemerintah dalam Penyelenggaraan Asuransi Kesehatan bagi Pegawai Negeri Sipil dan Penerima Pendisun serta Keputusan Bersama Menteri Kesehatan dan menteri Dalam Negeri Nomor 138/MENKES/PB/II/2009 dan Nomor 12 Tahun 2009 tentang Pedoman 
Tarif Pelayanan Kesehatan bagi Peserta PT. Akses (Persero) dan anggota keluarganya di Puskesmas, Balai Kesehatan Masyarakat dan Rumah Sakit Daerah. Terkait dengan hal tersebut, maka penyediaan anggaran untuk pengembangan cakupan tunjagnan kesehatan diluar cakupan pelayanan kesehatan yang disediakan asuransi kesehatan sebagaimana tersebut di atas, tidak diperkenankan dianggarkan dalam APBD, kecuali ditentukan lain berdasarkan peraturan perundang-undangan.

Pertumbuhan ekonomi adalah suatu kondisi dimana terjadi peningkatan produk domestic bruto dari suatu Negara atau daerah Pertumbuhan ekono dikatakan meningkat apabila persentase kenaikan Produk Domestik Bruto (PDB) pada suatu periode lebih besar dari periode sebelumnya.Kenaikan PDB tersebut tidak disertai perhitungan persentasenya terhadap tingkat pertumbuhan penduduk. Jadi, pertumbuhan ekonomi adalah suatu keadaan dimana terjadi kenaikan PDB suatu Negara tanpa memandang apakah kenaikan tersebut lebih besar atau lebih kecil dari tingkat pertumbuhan penduduk (Arsyad, 2005 : 7). Teori tersebut sejalan dengan teori pertumbuhan ekonomi yang dikemukakan oleh Budiono (1985) dalam Kuncoro (2004 : 129), yang menyatakan bahwa pertumbuhan ekonomi adalah proses kenaika output per kapita dalam jangka panjang.

Manfaat pertumbuhan ekonomi antara lain sebagai berikut : laju pertumbuhannya untuk mengukur kemajuan ekonomi sebagai hasil pembangunan nasional pendapatan perkapitanya dipergunakan untuk mengukur tingkat kemakmuran penduduk, sebab semakin meningkat pendapatan perkapita dengan kerja konstan semakin tinggi tingkat kemakmuran penduduk dan juga produktivitasnya, sebagai dasar pembuatan proyeksi atau perkiraan penerimaan Negara untuk perencanaan pembangunan nasional atau sektoral dan regional, sebagai dasar penentuan prioritas pemberian bantuan luar negeri oleh Bank Dunia atau lembaga internasional lainnya, sebagai dasar pembuatan prakiraan bisnis, khususnya persamaan penjualan bagi perusahaan untuk dasar penyusunan perencanaan produk dan perkembangan sumber daya (tenaga kerja dan modal) (http://jurnal.sdm.blogspot.com/2010/pertumbuhanekonomi-definisi-sumber.html).

Pertumbuhan ekonomi yang tinggi dan prosesnya yang berkelanjutan merupakan kondisi utama bagi kelangsungan pembangunan ekonomi, karena penduduk bertambah terus dan berarti kebutuhan ekonomi juga terus bertambah, maka dibutuhkan penambahan pendapatan setiap tahun. Hal ini hanya bisa di dapat lewat peningkatan output agregat (barang dan jasa) atau Produk Domestik Bruto (PDB) setiap tahun. Jadi dalam pengertian ekonomi makro, pertumbuhan ekonomi adalah penambahan PDB yang berarti juga penambahan pendapatan nasional (Tambunan, 2001). Pertumbuhan ekonomi bisa dilihat dalam nilai absolute dan nilai relative (persentase). Pertumbuhan dalam nilai absolute dinyatakan dalam rupiah, misalnya PDB tahun 2000 tumbuh Rp. 2 Triliun dibandingkan tahun 1999

UNDP (United Nation Development Programme) mendefenisikan pembangunan manusia sebagai suatu proses untuk memperluas pilihan-pilihan bagi penduduk. Dalam konsep tersebut penduduk ditempatkan sebagai tujuan akhir (the ultimate end) sedangkan upaya pembangunan dipandang sebagai sarana (principal means) untuk mencapai tujuan itu. Untuk menjamin tercapainya tujuan pembangunan manusia, empat hal pokok yang perlu diperhatikan adalah produktivitas, pemerataan, kesinambungan, pemberdayaan (UNDP, 1996).

\section{Metode Penelitian}

Rancangan yang digunakan dalam penelitian untuk mengetahui latar belakang masalah yang sedang dihadapi, konsep dasar pemikiran yang dijadikan acuan, pendekatan-pendekatan yang dipergunakan, hipotesis atau dugaan sementara yang diajukan untuk menjawab 
permasalahan, tehnik pengambilan atau pengumpulan data yang dipakai, dan analisis data statistik yang digunakan.

Jenis penelitian dari segi pendekatan dibagi menjadi dua macam, yaitu pendekatan kuantitatif dan pendekatan kualitatif. Sedangkan dalam penelitian ini menggunakan pendekatan kuantitatif. Pendekatan kuantitatif pada dasarnya menekankan analisisnya pada data numerical (angka) yang diolah dengan metode statistika. Pada dasarnya, pendekatan kuantitatif dilakukan pada penelitian inferensial (dalam rangka pengujian hipotesis) dan menyandarkan kesimpulan hasilnya pada suatu probabilitas kesalahan penolakan hipotesis nihil. Dengan metode kuantitatif akan diperoleh signifikansi perbedaan kelompok atau signifikansi hubungan antar variabel yang diteliti (Azwar, 2001 : 5). Jenis penelitian ini juga termasuk penelitian kualitatif deskriptif dengan kegiatan pengumpulan data dalam rangka menguji hipotesis dan mengukur dari data yang ada. Hipotesis merupakan merupakan jawaban sementara yang masih praduga untuk suatu masalah.Untuk membuktikan kebenarannya maka perlu penelitian lebih lanjut.

Definisi operasional variabel digunakan untuk memberikan petunjuk dalam operasional variabel penelitian, maka indikator pengukuran variael-variabel dijelaskan bahwa variabel penelitian yang digunakan dalam penelitian dibedakan ke dalam tiga kelompok variabel, yaitu variabel bebas (independent variables).Variabel terikat (dependent variables), dan variabel perantara (intervening variables) sebagai berikut:

1. Variabel bebas (X)

Variabel bebas adalah variabel yang diduga mempengaruhi variabel lain yang diteliti. Pada penelitian ini yang termasuk variabel bebas adalah variabel Belanja Modal $\left(\mathrm{X}_{1}\right)$ dan variabel Belanja Pegawai $\left(\mathrm{X}_{2}\right)$.

2. Variabel terikat (Y)

Variabel terikat adalah variabel yang tergantung terhadap variabel lain, atau variabel yang mendapat pengaruh dari variabel lain. Pada penelitian ini yang termasuk dalam variabel terikat adalah variabel Indeks Pembangunan Manusia (Y).

3. Variabel Perantara (Z)

Variabel perantara digunakan jika dalam suatu model penelitian dianggap terdapat variabel lain yang dapat mempengaruhi variabel terikat, namun tidak mempunyai pengaruh utama (Nazir, 2005 : 125). Pada penelitian ini yang termasuk variabel perantara adalah variabel Pertumbuhan Ekonomi Daerah (Z).

Secara ringkas operasionalisasi variabel dalam penelitian ini dapat terlihat seperti pada Tabel 1.

Data yang digunakan dalam penelitian ini adalah data sekunder, yaitu data yang diperoleh, dikumpulkan dan diolah terlebih dahulu oleh pihak lain. Sumber data dalam penelitian ini adalah

1. Data strategis diperoleh dari Badan Pusat Statistik Kabupaten Hulu Sungai Tengah (HST), untuk mengetahui realisasi produk domestic regional bruto (PDRB) Tahun 2010-2016.

2. Indikator Penting Sosial Ekonomi Kalimantan Selatan Diperoleh dari Badan Pusat Statistik Kabupaten HST, untuk mengetahui Indek Pembangunan Manusia (IPM) Tahun 20102016.

3. Kabupaten Hulu Sungai Tengah dalam Angka in figures 2010 (Katalog BPS: 1403:6212).

4. Laporan Keuangan Kabupaten Hulu Sungai TengahTahun2010-2016, yang digunakan untuk mengetahui realisasi Anggaran Belanja Modal dan Belanja Pegawai. 
Fajerin, Tata Kelola Belanja Modal dan Belanja Pegawai Untuk Peningkatan Pertumbuhan Ekonomi.

Tabel 1. Definisi Operasional Variabel

\begin{tabular}{|c|c|c|c|c|c|}
\hline $\begin{array}{l}\text { Jenis } \\
\text { Variabel }\end{array}$ & $\begin{array}{l}\text { Nama } \\
\text { Variabel }\end{array}$ & Definisi varbl. & Sumber & Kriteria/ukuran & $\begin{array}{l}\text { Skala } \\
\text { Pengukuran }\end{array}$ \\
\hline Dependen & $\begin{array}{l}\text { Indeks } \\
\text { Pembangunan } \\
\text { Manusia (Y) }\end{array}$ & $\begin{array}{l}\text { Variabel terikat }(\mathrm{Y}) \\
\text { adalah } \\
\text { Variabel terikat adalah } \\
\text { variabel yang } \\
\text { tergantung terhadap } \\
\text { variabel lain, atau } \\
\text { variabel yang } \\
\text { mendapat pengaruh } \\
\text { dari variabel lain. }\end{array}$ & $\begin{array}{l}\text { Kabupaten Hulu } \\
\text { Sungai Tengah } \\
\text { dalam Angka } \\
\text { Tahun 2010- } \\
2016\end{array}$ & $\begin{array}{l}\text { IPM }=1 / 3\left[X_{(1)}+X_{(2)}\right. \\
\left.+X_{(3)}\right] \\
\text { Dimana : } \\
X_{(1): \text { Indeks harapan }} \\
\text { hidup } \\
X_{(2)} \text { : Indeks } \\
\text { pendidikan } \\
X_{(3)}: \text { Indeks standar } \\
\text { hidup layak }\end{array}$ & Rasio \\
\hline Independen & $\begin{array}{l}\text { Belanja } \\
\text { Modal } \\
\left(\mathrm{X}_{1}\right)\end{array}$ & $\begin{array}{l}\text { Variabel bebas }(\mathrm{X}) \\
\text { Variabel bebas adalah } \\
\text { variabel yang diduga } \\
\text { mempengaruhi variabel } \\
\text { lain yang diteliti. Pada } \\
\text { penelitian ini yang } \\
\text { termasuk variabel } \\
\text { bebas }\end{array}$ & $\begin{array}{l}\text { Laporan APBD } \\
\text { Kabupaten Hulu } \\
\text { Sungai } \\
\text { TengahTahun } \\
\text { 2010-2016 }\end{array}$ & $\begin{array}{l}\text { Anggaran Belanja } \\
\text { Modal tahun 2010- } \\
2016\end{array}$ & Rasio \\
\hline Independen & $\begin{array}{l}\text { Belanja } \\
\text { Pegawai }\left(\mathrm{X}_{2}\right)\end{array}$ & $\begin{array}{l}\text { Variabel bebas }(\mathrm{X}) \\
\text { adalah } \\
\text { Variabel bebas adalah } \\
\text { variabel yang diduga } \\
\text { mempengaruhi variabel } \\
\text { lain yang diteliti. Pada } \\
\text { penelitian ini yang } \\
\text { termasuk variabel } \\
\text { bebas }\end{array}$ & $\begin{array}{l}\text { Laporan APBD } \\
\text { Kabupaten Hulu } \\
\text { Sungai } \\
\text { TengahTahun } \\
\text { 2010-2016 }\end{array}$ & $\begin{array}{l}\text { Anggaran Belanja } \\
\text { Modal Tahun 2010- } \\
2016\end{array}$ & Rasio \\
\hline Perantara & $\begin{array}{l}\text { Pertumbuhan } \\
\text { Ekonomi } \\
\text { Daerah }(Z)\end{array}$ & $\begin{array}{l}\text { Variabel Perantara }(\mathrm{Z}) \\
\text { adalah } \\
\text { Variabel perantara } \\
\text { digunakan jika dalam } \\
\text { suatu model penelitian } \\
\text { dianggap terdapat } \\
\text { variabel lain yang } \\
\text { dapat mempengaruhi } \\
\text { variabel terikat, namun } \\
\text { tidak mempunyai } \\
\text { pengaruh utama }\end{array}$ & $\begin{array}{l}\text { Laporan Hasil } \\
\text { Pertumbuhan } \\
\text { Ekonomi Tahun } \\
\text { 2010-2016 }\end{array}$ & $\begin{array}{l}\triangle \mathrm{PDRB}(\mathrm{t})= \\
\frac{P D R B(t)-P D R B(t-}{P D R B(t-1)} \\
\text { Dimana } \\
\triangle \mathrm{PDRB}(\mathrm{t})= \\
\text { Pertumbuhan } \\
\text { Ekonomi tahun }(\mathrm{t}) \\
\text { tertentu dengan nilai } \\
\text { absolute } \\
(\mathrm{t}-1)=\text { tahun } \\
\text { sebelumnya }\end{array}$ & Rasio \\
\hline
\end{tabular}

Untuk memperoleh data yang relevan sehingga dapat dianalisis, maka diperlukan pengumpulan data dengan metode dokumentasi.dimana data yang digunakan dalam penelitian ini dikumpulkan dengan metode dokumentasi dengan mempelajari dokumen-dokumen. Sumber dan penggunaannya dengan data statistic yang didapat dari data eksternal yaitu data yang diperoleh dari BPS (Badan Pusat Statistik). Sifat datanya adalah data kuantitatif yaitu data yang berupa angka-angka, dan bersifat obyektif.

Teknik analisis data merupakan metode yang penting dalam metode ilmiah karena dengan analisis, data diberi arti dan makna yang berguna dalam memecahkan masalah penelitian yaitu:

1. Uji Autokorelasi

Autokorelasi adalah adanya korelasi antara anggota sampel serangkaian observasi yang diurutkan berdasarkan waktu. Penyimpangan ini biasanya muncul pada observasi yang 
menggunakan data time series. Autokorelasi dapat diukur dengan Durbin-Watson Statistic (Ghozali, 2006), dengan ketentuan sebagai berikut:

Tabel 2. Kriteria Autokorelasi

\begin{tabular}{ll}
\hline Durbin Watson & Kesimpulan \\
\hline $0<\mathrm{d}<\mathrm{dl}$ & Terdapat autokorelasi positif \\
$\mathrm{d} l \leq \mathrm{d} \leq \mathrm{du}$ & Tidak terdapat kesimpulan \\
$4-\mathrm{dl}<\mathrm{d}<4$ & Terdapat autokorelasi negative \\
$4-\mathrm{du} \leq \mathrm{d} \leq 4-\mathrm{dl}$ & Tidak terdapat kesimpulan \\
$\mathrm{du}<\mathrm{d}<4-\mathrm{du}$ & Tidak ada autokorelasi, positif atau negatif \\
\hline
\end{tabular}

2. Uji Heteroskedastisitas

Heterokedastisitas adalah varian residual dalam model tidak homogeny. Akibat dari adanya heterokedastisitas adalah penaksiran OLS tetap tidak efesien, baik dalam sampel kecil maupun besar.uji untuk mendeteksi adanya gejala heterokedastisitas dilakukan dengan uji glejse. Uji glejser dilakukan dengan meregresikan absolute residual dengan variabel independen.

Berdasarkan dugaan awal/hipotesis dalam penelitian ini maka dapat dibuat model analisis jalur (path analysis) pada penelitian ini adalah seperti pada Gambar 1.

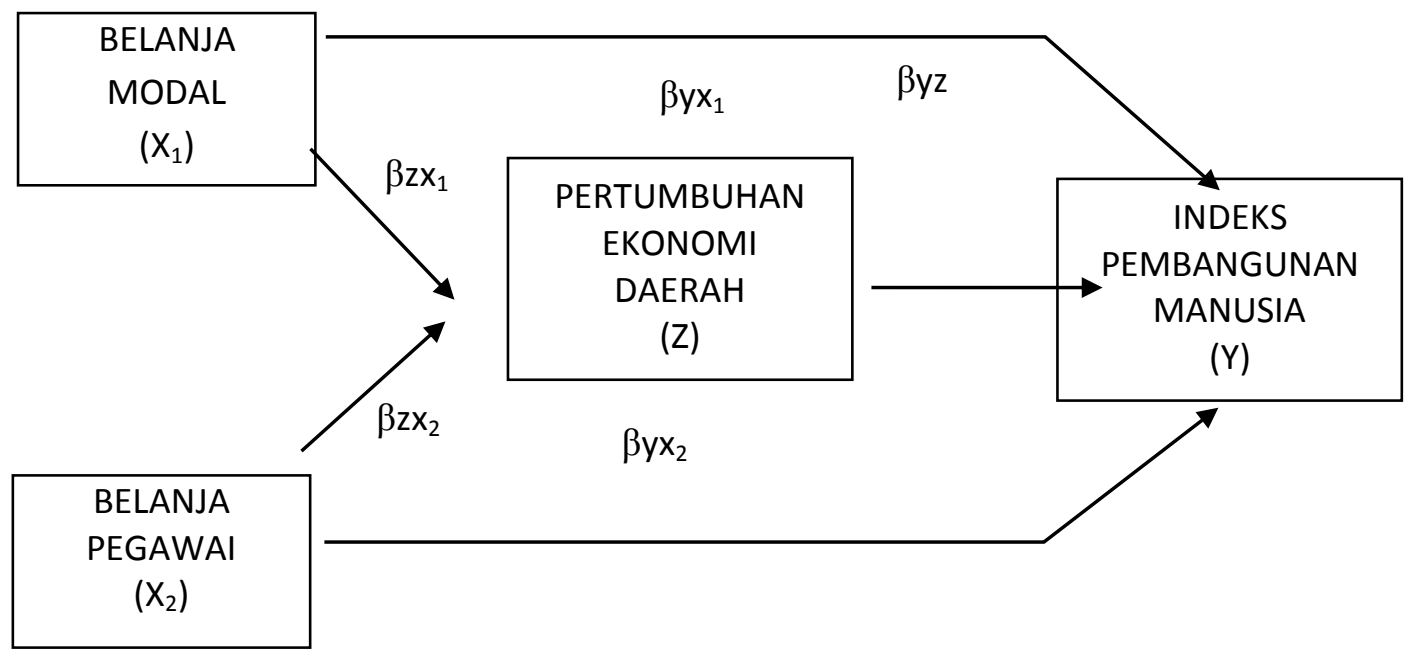

Gambar 1. Model Analisis Jalur (Path Analysis)

Model tersebut pada Gambar 1 bila dinyatakan dalam bentuk persamaan model structural, maka akan Nampak sebagai berikut:

a. $\mathrm{Z}: \beta 0+\beta \mathrm{zx}_{1}+\beta \mathrm{zx}_{2}+\mathrm{E}_{1} \mathrm{E}_{1}=\longrightarrow\left(1-\mathrm{R}^{2}\right)^{2}$

b. $\mathrm{Y}: \beta_{0}+\beta \mathrm{yx}_{1}+\beta \mathrm{yx}_{2}+\beta \mathrm{yz}+\mathrm{E}_{1} \mathrm{E}_{2}=\rightarrow\left(1-\mathrm{R}^{2}\right)^{2}$

Dimana :

$\mathrm{X}_{1}=$ Belanja Modal

$\mathrm{X}_{2}=$ Motivasi

$\mathrm{Z}=$ pertumbuhan ekonomi daerah

$\mathrm{Y}=$ Indeks Pembangunan Manusia

$\mathrm{B}_{0}=$ Intercept

$\mathrm{E}_{1}=$ Residual Variable/error 
berikut :

Asumsi yang melandasi pembuatan analisis jalur dalam penelitian ini adalah sebagai

1. Di dalam model analisis jalur, hubungan antar variabel adalah linier dan aditif.

2. Hanya model rekursif yang dapat dipertimbangkan, yaitu hanya sistem aliran kausal ke satu arah, sedangkan pada model yang mengandung kausal resiprokal, analisis jalur tidak dapat dilakukan.

3. Variabel endogen minimal dalam skala ukur interval.

4. Model yang dianalisis dispesifikasikan (diidentifikasikan) dengan benar berdasarkan teoriteori dan konsep-konsep yang relevan.

\section{Hasil Penelitian dan Pembahasan}

Analisis data dalam penelitian ini meliputi deskripsi data, uji asumsi klasik dan uji Regresi.Uji asumsi klasik meliputi uji normalitas, multikolinieritas, autokorelasi, dan heteroskedastisitas.Pengujian hipotesis dalam penelitian ini dilakukan dengan menggunakan analisis regresi linier berganda. Analisis regresi berganda dilakukan bertahap untuk menganalisis model dengan dua variabel atau lebih variabel independen.

Data-data mengenai Belanja Modal, Belanja Pegawai, Pertumbuhan ekonomidaerah dan Indeks Pembangunan Manusia (IPM) di Kabupaten Hulu Sungai Tengah ditunjukkan pada Tabel 3.

Tabel 3. Data Belanja Modal, Belanja Pegawai, Pertumbuhan Ekonomi dan Indeks Pembangunan Manusia (IPM)

\begin{tabular}{lcclc}
\hline \multicolumn{1}{c}{ Variabel } & Minimum & Maximum & Mean & Std. Deviation \\
\hline Belanja Modal & 14,91 & 26,21 & 19,8176 & 2,14353 \\
\hline Belanja Pegawai & 16,00 & 26,43 & 21,5588 & 1,21164 \\
\hline Pertumbuhan Ekonomi & 3,84 & 6,21 & 5,4985 &, 78203 \\
\hline \multicolumn{1}{c}{ IPM } & 63,49 & 67,07 & 65,0663 & 1,24101 \\
\hline
\end{tabular}

Selanjutnya mulai dilakukan pengujian secara statistik. Langkah analisis yang pertamatama dilakukan adalah uji asumsi klasik, yang terdiri dari:

1. Uji Normalitas

Uji normalitas yang dimaksud untuk mengetahui apakah data berdistribusi normal atau tidak.Pengujian normalitas menggunakan teknik analisis Kolmogorov-Smornov. Hasil analisis menyatakan bahwa data residual berdistribusi normal jika probabilitas lebih besar dari taraf signifikansi 5\% (p>0,05). Hasil uji normalitas dapat dilihat pada Tabel 4.

Tabel 4. Hasil Uji Normalitas

\begin{tabular}{ccc}
\hline Variabel & Sig & Keterangan \\
\hline Unstandardized Residual & 0,065 & Normal \\
\hline
\end{tabular}

Tabel 4 Menunjukkan bahwa data data penelitian berdistribusi normal yang ditunjukkan dengan nilai signifikansi pada uji normalitas sebesar 0,065 lebih besar dari 0,05 ( $>>0,05)$.

2. Uji Multikolinieritas

Uji multikolinieritas dilakukan untuk mengetahui besarnya interkolerasi antar variabel bebas dalam penelitian ini.Jika terjadi korelasi, maka dinamakan terdapat masalah multikolinieritas.Untuk mendeteksi ada tidaknya multikulinieritas dapat dilihat pada nilai 
tolerance dan VIF. Apabila nilai toleransi di atas 0,01 dan nilai VIF di bawah 10 maka tidak terjadi multikolinieritas. Hasil uji multikolinieritas dapat dilihat pada Tabel 6.

Tabel 6. Hasil Uji Multikolinieritas

\begin{tabular}{lccl}
\hline \multicolumn{1}{c}{ Variabel } & Tolerance & VIF & Kesimpulan \\
\hline Belanja Modal & 0,636 & 1,573 & Tidak terjadi multikolinieritas \\
\hline Belanja Pegawai & 0,638 & 1,567 & Tidak terjadi multikolinieritas \\
\hline Pertumbuhan Ekonomi & 0,989 & 1,011 & Tidak terjadi multikolinieritas \\
\hline
\end{tabular}

Tabel 6 menunjukkan bahwa variabel belanja modal, belanja pegawai, dan pertumbuhan ekonomi mempunyai nilai toleransi di atas 0,1 dan nilai VIF di bawah 10 , sehingga dapat disimpulkan bahwa modal regresi pada penelitian ini tidak terjadi multikolinieritas.

\section{Uji Autokolerasi}

Autokolerasi adalah adanya korelasi antara anggota sampel serangkaian observasi yang diurutkan berdasarkan waktu. Penyimpangan ini biasanya muncul pada observasi yang menggunakan data time series. Autokolerasi dapat diukur dengan Durbin Watson.Statistic dan hasil pengujian diketahui nilai Durbin-Watson sebesar 0,073.Nilai durbin Watson berada diantara -2 sampai 2. Dengan demikian dapat disimpulkan bahwa tidak terdapat autokorelasi dalam penelitian ini.

\section{Uji Heteroskedastisitas}

Heterokedastisitas adalah varian residual dalam model tidak homogeny.Uji untuk mendeteksi adanya gejala heterokedastisitas dilakukan dengan uji glesjer.Uji glejser dilakukan dengan meregresikan absolute residual dengan variabel independen.Model dinyatakan tidak terjadi heteroskedastisitas jiga probabilitas lebih besar dari taraf signifikansi 5\%.Hasil uji heteroskedastisitas dapat dilihat pada Tabel 7.

\section{Tabel 7. Hasil Uji Heteroskedastisitas}

\begin{tabular}{lll}
\hline Variabel & Sig & Kesimpulan \\
\hline Belanja Modal & 0,939 & Tidak terjadi heteroskedastisitas \\
\hline Belanja Pegawai & 0,154 & Tidak terjadi heteroskedastisitas \\
\hline $\begin{array}{l}\text { Pertumbuhan } \\
\text { Ekonomi }\end{array}$ & 0,983 & Tidak terjadi heteroskedastisitas \\
\hline
\end{tabular}

Tabel 7 menunjukkan bahwa variabel independen tidak terjadi heteroskedastisitas yang ditunjukkan dengan nilai signifikansi lebih besar dari 0,05 ( $p>0,05)$.

Pengujian hipotesis dalam penelitian ini digunakan untuk membuktikan secara empiris pengaruh belanja modal dan belanja pegawai terhadap pertumbuhan ekonomi daerah di Kabupaten Hulu Sungai Tengah tahun 2010-2016, pengaruh belanja modal dan belanja pegawai terhadap indeks pembangunan manusia (IPM) di Kabupaten Hulu Sungai Tengah tahun 2010-2016, dan pengaruh pertumbuhan ekonomi terhadap Indeks Pembangunan Manusia (IPM) di Kabupaten Hulu Sungai Tengah tahun 2010-2016. Pengujian hipotesis ini menggunakan uji regresi berganda yang dilakukan dengan menggunakan program SPSS.

1. Pengujian Hipotesis 1 dan 2

Hipotesis pertama $\left(\mathrm{H}_{1}\right)$ dalam penelitian ini adalah belanja modal berpengaruh signifikan terhadap pertumbuhan ekonomi sedangkan hipotesis kedua $\left(\mathrm{H}_{2}\right)$ dalam penelitian ini adalah belanja pegawai berpengaruh signifikan terhadap pertumbuhan ekonomi. Berdasarkan pengujian analisis regresi yang telah dilakukan maka didapatkan hasil yang disajikan Tabel 8. 
Tabel 8. Rangkuman Hasil Analisis Regresi Pengujian Hipotesis 1 dan 2

\begin{tabular}{llllll}
\hline Variabel & B & S.C Beta & $t_{\text {hitung }}$ & Sig & Kesimpulan \\
\hline Belanja Modal $\left(\mathrm{X}_{1}\right)$ & 0,030 & 0,083 & 1,098 & 0,273 & Tidak Signifikan \\
\hline Belanja Pegawai $\left(\mathrm{X}_{2}\right)$ & 0,018 & 0,029 & 0,378 & 0,706 & Tidak Signifikan \\
\hline Konstanta $=4,501$ & & & & & \\
\hline $\mathrm{R}^{2}=0,011$ & & & & & \\
\hline $\mathrm{F}$ hitung $=1,446$ & & & & & \\
\hline Sig. $=0,237$ & &
\end{tabular}

Berdasarkan hasil analisis regresi pengujian $\mathrm{H}_{1}$ dan $\mathrm{H}_{2}$ yang disajikan pada tabel 1.8 di atas menyatakan bahwa nilai $\mathrm{F}$ hitung sebesar 1,446 lebih besar dari $\mathrm{F}$ tabel sebesar 3,04 dengan nilai signifikansi 0,237 lebih besar dari 0,05 ( $\mathrm{p}<0,05)$. Hal ini menunjukkan bahwa nilai $\mathrm{F}$ hitung tersebut tidak signifikan sehingga tidak terdapat pengaruh belanja modal dan belanja pegawai secara simultan terhadap variabel dependen yaitu pertumbuhan ekonomi. Untuk pengujian hipotesis pertama $\left(\mathrm{H}_{1}\right)$ pada Tabel 1.8, diperoleh nilai koefesien standardized beta (S.C Beta) sebesar 0,083 yang merupakan nilai jalur (path), sedangkan koefesien regresi $(\beta)$ variabel belanja modal sebesar 0,030dan nilai t hitung sebesar 1,098 lebih besar dari t tabel sebesar 1,960 dengan nilai signifikansi 0,273 lebih besarl dari 0,05 $(\mathrm{p}<0,05)$. Hal ini menunjukkan bahwa tidak terdapat pengaruh belanja modal terhadap pertumbuhan ekonomi secara positif dan signifikan. Dengan demikian, hipotesis pertama $\left(\mathrm{H}_{1}\right)$ yang menyatakan bahwa "Belanja modal berpengaruh positif signifikan terhadap pertumbuhan ekonomi di Kabupaten Hulu Sungai Tengah tahun 2010-2016" tidak dapat diterima.Untuk pengujian hipotesis kedua $\left(\mathrm{H}_{2}\right)$ pada Tabel 1.8 , diperoleh nilai koefesien standardized beta (S.C Beta) sebesar 0,029 yang merupakan nilai jalur (path), sedangkan koefesien regresi $(\beta)$ variabel kompetensi sebesar 0,018 dan nilai t hitung sebesear 0,378 lebih kecil dari t tabel sebesar 1,960 dengan nilai signifikansi 0,706 lebih besar dari 0,05 $(\mathrm{p}>0,05)$. Hal ini menunjukkan bahwa tidak terdapat pengaruh belanja pegawai terhadap pertumbuhan ekonomi adalah positif dan signifikan. Berpengaruh positif berarti semakin tinggi belanja pegawai, maka akan meningkatkan pertumbuhan ekonomi. Dengan demikian hipotesis kedua $\left(\mathrm{H}_{2}\right)$ yang menyatakan bahwa "Belanja pegawai berpengaruh positif signifikan terhadap pertumbuhan ekonomi di Kabupaten Hulu Sungai Tengah tahun 2010-2016" tidak dapat diterima.

2. Pengujian Hipotesis 3, 4, dan 5

Hipotesis ketiga $\left(\mathrm{H}_{3}\right)$ dalam penelitian ini adalah belanja modal berpengaruh signifikan terhadap Indeks Pembangunan Manusia (IPM) di Kabupaten Hulu Sungai Tengah tahun 2010-2016, sedangkan hipotesis keempat $\left(\mathrm{H}_{4}\right)$ dalam penelitian ini adalah belanja pegawai berpengaruh signifikan terhadap Indeks Pembangunan Manusia (IPM) di Kabupaten Hulu Sungai Tengah tahun 2010-2016. Berdasarkan pengujian analisis regresi yang telah dilakukan maka didapatkan hasil yang disajikan tabel 9.

Tabel 9. Rangkuman Hasil Analisis Regresi Pengujian Hipotesis 3 dan 4

\begin{tabular}{llllll}
\hline Variabel & B & S.C Beta & $\mathbf{t}_{\text {hitung }}$ & Sig & Kesimpulan \\
\hline Belanja Modal $\left(\mathrm{X}_{1}\right)$ & $-0,078$ & $-0,135$ & $-2,445$ & 0,015 & Signifikan \\
\hline Belanja Pegawai $\left(\mathrm{X}_{2}\right)$ & 0,131 & 0,128 & 2,322 & 0,021 & Signifikan \\
\hline Pertumbuhan Ekonomi $\left.\mathrm{X}_{3}\right)$ & 1,088 & 0,686 & 15,526 & 0,000 & Signifikan \\
\hline Konstanta $=57,810$ & & & & & \\
\hline $\mathrm{R}^{2}=0,479$ & & & & & \\
\hline $\mathrm{F}$ hitung $=82,762$ & & & & & \\
\hline Sig. $=0,000$ & &
\end{tabular}


Berdasarkan hasil analisis regresi pengujian $\mathrm{H}_{3}, \mathrm{H}_{4}$, dan $\mathrm{H}_{5}$ yang disajikan pada tabel 1.9 di atas menyatakan bahwa nilai $\mathrm{F}$ hitung sebesar 82,762 lebih besar dari $\mathrm{F}$ tabel sebesar 2,64 dengan nilai signifikansi $0,000(\mathrm{p} \leq 0,05)$. Hal ini menunjukkan bahwa nilai $\mathrm{F}$ hitung tersebut signifikan sehingga model regresi linier penelitian ini dapat digunakan untuk menjelaskan pengaruh-pengaruh dari variabel independen yaitu belanja modal, belanja pegawai, dan pertumbuhan ekonomi secara simultan terhadap variabel dependen yaitu IPM.

Berdasarkan hasil pada tabel 1.9 diketahui bahwa nilai koefesien standardized beta (S.C Beta) sebesar $-0,135$ yang merupakan nilai jalur (path), sedangkan nilai koefisien regresi sebesar -0,078 dengan arah negatif dan nilai t hitung sebesar -2,445 lebih besar dari t tabel sebesar 1,960 (arah negatif) dengan nilai signifikansi 0,015 lebih kecil dari 0,05 ( $\mathrm{p}<0,05)$. Hal ini menunjukkan bahwa ada pengaruh belanja modal terhadap IPM secara negatif dan signifikan. Dengan demikian hipotesis ketiga $\left(\mathrm{H}_{3}\right)$ yang menyatakan bahwa "Belanja modal berpengaruh positif signifikan terhadap indeks pembangunan maunsia (IPM) di Kabupaten Hulu Sungai Tengah Tahun 2010-2016" tidak dapat diterima.

Untuk pengujian hipotesis keempat $\left(\mathrm{H}_{4}\right)$ pada tabel 1.9 diperoleh nilai koefesien standardized beta (S.C Beta) sebesar 0,128 yang merupakan nilai jalur (path), sedangkan koefesien regresi $(\beta)$ variabel belanja pegawai sebesar 0,131 dan nilai $t$ hitung sebesar 2,322 lebih besar dari t tabel sebesar 1,960 dengan nilai signifikansi 0,021 lebih kecil dari 0,05 $(\mathrm{p}<0,05)$. Hal ini menunjukkan bahwa ada pengaruh belanja pegawai terhadap IPM adalah positif dan signifikan. Berpengaruh positif berarti semakin tinggi belanja pegawai, maka akan meningkatkan IPM. Dengan demikian hipotesis keempat $\left(\mathrm{H}_{4}\right)$ yang menyatakan bahwa "Belanja pegawai berpengaruh positif signifikan terhadap IPM di Kabupaten Hulu Sungai Tengah tahun 2010-2016” dapat diterima.

Pada pengujian hipotesis kelima $\left(\mathrm{H}_{5}\right)$ pada Tabel 1.9 , diperoleh nilai koefesien standardized beta (S.C Beta) sebesar 0,686 yang merupakan nilai jalur (path), sedangkan koefesien regresi $(\beta)$ variabel pertumbuhan ekonomi daerah sebesar 1,088 dan nilai t hitung sebesar 15,526 lebih besar dari t tabel sebesar 1,960 dengan nilai signifikansi 0,000 lebih kecil dari $0,05(\mathrm{p}<0,05)$. Hal ini menunjukkan bahwa ada pengaruh pertumbuhan ekonomi terhadap IPM secara positif dan dignifikan.Berpengaruh positif berarti semakin tinggi pertumbuhan ekonomi, maka akan meningkatkan IPM. Dengan demikian hipotesis kelima $\left(\mathrm{H}_{5}\right)$ yang menyatakan bahwa "Pertumbuhan ekonomi berpengaruh positif signifikan terhadap IPM di Kabupaten Hulu Sungai Tengah tahun 2010-2016" dapat diterima.

Penelitian ini dilakukan untuk membuktikan secara empiris manjemen belanja modal dan belanja pegawai berpengaruh terhadap pertumbuhan ekonomi daerah dan Indeks Pembangunan Manusia di Kabupaten Hulu Sungai Tengah tahun 2010-2016, . Meskipun belanja modal tidak berpengaruh positif dan tidak signifikan terhadap pertumbuhan ekonomi daerah di Kabupaten Hulu Sungai Tengah tahun 2010-2016.Hal ini ditunjukkan dari penganalisaan hipotesis pertama $\left(\mathrm{H}_{1}\right)$, dan pengeluaran anggaran untuk perolehan aset tetap dan aset lainnya memberi manfaat lebih dari satu periode akuntansi, sedangkan pertumbuhan ekonomi adalah suatu kondisi dimana terjadi peningkatan produk domestic bruto dari suatu Negara atau daerah. Peningkatan alokasi belanja modal dalam bentuk aset tetap seperti infrastruktur, peralatan dan infrastruktur akan semakin meningkatkan belanja modal dan diharapkan akan semakin tinggi pula produktivitas perekonomian. Namun dalam penelitian ini belanja modal tidak memengaruhi pertumbuhan ekonomi masyarakat suatu daerah. Kondisi mungkin karena masih kecilnya proporsi belanja modal yang hanya berkisar $12,0 \%$ s/d 14,5\% dari APBD tahun 2010 - 2016. Pertumbuhan ekonomi dengan mengelola sumber daya yang ada dan membentuk suatu pola kemitraan dengan masyarakat, seharusnya akan menciptakan lapangan pekerjaan baru yang akan mempengaruhi perkembangan kegiatan ekonomi dalam daerah tersebut. Pembangunan ekonomi ini ditandai dengan meningkatnya 
produktivitas dan meningkatnya pendapatan per kapita penduduk sehingga terjadi perbaikan kesejahteraan.

Hasil penelitian ini tidak mendukung penelitian sebelumnya yang dilakukan oleh Gregoriou dan Ghosh (2006), yang dalam penelitiannya menunjukkan bahwa belanja pemerintah, yang didalamnya termasuk belanja modal dan belanja pegawai mempunyai pengaruh yang sangat kuat terhadap pertumbuhan ekonomi. Hal ini mengindikasikan bahwa pemerintah daerah belum menggunakan sumber daya secara efektif dan efisien.Dilihat dari alokasi belanja modal yang tidak menentu setiap tahunnya (ada yang naik dan turun), masih banyak daerah yang belum secara optimal menyadiakan fasilitas umum yang memadai.Tetapi walaupun fasilitas tersebut masih minim, pertumbuhan ekonomi mengalami progres yang cukup baik dengan persentase pertumbuhan PDRB yang meningkat dari tahun ke tahun. Temuan ini mengindikasikan adanya faktor lain yang mempengaruhi pertumbuhan ekonomi daerah selain belanja modal.

Belanja pegawai tidak berpengaruh positif dan tidak signifikan terhadap pertumbuhan ekonomi daerah di Kabupaten Hulu Sungai Tengah tahun 2010-2016.Hal ini ditunjukkan dari penganalisaan hipotesis kedua $\left(\mathrm{H}_{2}\right)$. Hasil penelitian ini tidak mendukung penelitian sebelumnya yang dilakukan oleh Gregoriou dan Ghosh (2006). Belanja pegawai tidak berpengaruh terhadap tinggi atau rendahnya pertumbuhan ekonomi daerah. Belanja pegawai adalah semua pengeluaran yang digunakan untuk membiayai kompensasi dalam bentuk yang atau barang yang diberikan kepada pegawai daerah.Belanja pegawai dapat berupa gaji, pensiunan, tunjangan beras, uang makan, dan lain-lain termasuk juga pengeluaran dalam rangka meningkatkan kualitas aparatur pemerintahan, agar pegawai negeri dapat meningkatkan kualitas pelayanan kepada masyarakat.Hasil penelitian menunjukkan bahwa belanja pegawai tidak berpengaruh terhadap pertumbuhan ekonomi.Hal ini dikarenakan banyak pegawai yang tidak berdomisili di daerah tersebut.Sehingga meskipun anggaran belanja pegawai selalu mengalami peningkatan tidak berdampak pada pertumbuhan ekonomi. Belanja pegawai tidak secara langsung akan memengaruhi pertumbuhan ekonomi, karena selain proporsinya yang hanya $23,2 \%$ dalam APBD, belanja pegawai yang sebagaian besar adalah pembayaran gaji dan tunjangan pegawai, kemungkinan tidak seluruhnya dibelanjakan di daerah Hulu Sungai Tengah, namun sangat dimungkinkan dibelanjakan di luar wilayah Hulu Sungai Tengah yang umumnya untuk pembiayaan gaya hidup. Karena inilah belanja pegawai tidak secara langsung dapat memengaruhi pertumbuhan ekonomi masyarakat Hulu Sungai Tengah.

Hasil penelitian menunjukkan bahwa belanja modal berpengaruh negatif dan signifikan terhadap indeks pembangunan manusia di Kabupaten Hulu Sungai Tengah tahun 2010 2016. Hal ini ditunjukkan dari penganalisaan hipotesis ketiga $\left(\mathrm{H}_{3}\right)$. Hasil penelitian ini tidak sesuai dengan penelitian sebelumnya yang dilakukan oleh Christy dan Adi (2009) yang dalam penelitiannya menunjukkan bahwa kualitas pembangunan manusia sangat tergantung dari adanya dana alokasi umum yang berasal dari pemerintah pusat dan juga besarnya belanja daerah yang dianggarkan di daerah untuk menunjang pembangunan manusia. Pemberian otonomi daerah melalui peningkatan ekonomi diharapkan dapat memacu peningkatan kesejahteraan masyarakat. Dalam upaya peningkatan kesejahteraan masyarakat tersebut perlu diprioritaskan alokasi belanja dalam penyusunan anggaran daerah. Indeks pembangunan manusia akan rendah akan menentukan tingkat kesejahteraan individu yang pada akhirnya akan menentukan tingkat kesejahteraan masyarakat secara umum.

Berdasarkan hasil penelitian ini diketahui bahwa semakin tinggi belanja daerah akan menurunkan indeks pembangunan manusia. Anggaran belanja modal naik turun dari tahun ke tahun. Besarnya belanja modal seharusnya diikuti dengan keefektifan belanja modal untuk kepentingan publik yang akan secara langsung berdampak kepada kegiatan pembangunan di daerah tersebut. Namun kenyataannya anggaran belanja modal yang besar digunakan untuk 
penambahan asset seperti jalan, gedung, tanah, dan lain-lain. Sementara Indeks Pembangunan Manusia dimensinya adalah unsur kesehatan, pendidikan dan perekonomian. Hal ini yang mengakibatkan menurunnya indeks pembangunan manusia. Karena manfaat dari penggunaan modal tersebut tidak dapat dirasakan secara langsung, akan tetapi dapat dirasakan manfaatnya dalam masa waktu yang cukup panjang.

Berdasarkan hasil penelitian diketahui bahwa belanja pegawai berpengaruh positif dan signifikan terhadap indeks pembangunan manusia di Kabupaten Hulu Sungai Tengah tahun 2010 - 2016. Hal ini ditunjukkan dari penganalisaan hipotesis keempat $\left(\mathrm{H}_{4}\right)$.Belanja pegawai merupakan salah satu jenis pengeluaran pemerintah daerah yang tertuang dalam APBD.Setiap tahun pengeluaran ini selalu ada dalam APBD.Dalam APBD belanja pegawai termasuk dalam kategori belanja operasi, pemeliharaan sarana dan prasarana public, yang merupakan pengeluaran pemerintah daerah yang berhubungan dengan aktivitas atau pelayanan public. Belanja pegawai merupakan pengeluaran pemerintah daerah untuk orang/personal yang berhubungan dengan suatu aktivitas atau dengan kata lain merupakan belanja pegawai yang bersifat variabel. Penggunaan belanja belanja pegawai secara proporsional dapat dilakukan pembangunan secara komprehensif, yaitu pembangunan secara fisik khususnya bagi para pegawai dan secara muti player berdampak pada ekonomi masyarakat suatu daerah, meskipun kecil. Peningkatan ekonomi pegawai, dan pembangunan sumber daya manusia melalui peningkatan performa dari pegawai negeri sipil di lingkungan pemerintah daerah. Dengan demikian semakin tinggi belanja pegawai mampu meningkatkan indeks pembangunan manusia. Hasil penelitian ini sejalan dengan penelitian sebelumnya yang dilakukan oleh Gregoriou dan Ghosh (2006) yang menyatakan belanja pegawai berpengaruh terhadap indeks pembangunan manusia.

Pertumbuhan ekonomi daerah berpengaruh positif dan signifikan terhadap indeks pembangunan manusia (IPM) di Kabupaten Hulu Sungai Tengah tahun 2010-2016.Hal ini ditunjukkan dari penganalisaan hipotesis kelima $\left(\mathrm{H}_{5}\right)$. Hasil penelitian ini sesuai dengan penelitian sebelumnya yang dilakukan oleh Ranis dan Stewart (2002) yang dalam penelitiannya menunjukkan bahwa pembangunan manusia mempunyai pengaruh yang cukup kuat terhadap pertumbuhan ekonomi di Amerika Latin, namun sebaliknya pertumbuhan ekonomi mempunyai pengaruh yang sangat lemah terhadap pembangunan manusia di Amerika Latin yang disebabkan pada saat itu sedang terjadi krisis hutang. Semakin tinggi pertumbuhan ekonomi daerah manusia akan meningkatkan indeks pembangunan manusia. Indikator ekonomi merupakan salah satu indikator utama dalam indeks pembangunan manusia selain indikator kesehatan dan tingkat pendidikan.

Perbaikan pengalokasian dana dapat membantu dalam perbaikan dan peningkatan kesejahteraan masyarakat. Hubungan antara pertumbuhan ekonomi dan pembangunan ekonomi bersifat timbal balik, yang artinya apabila terdapat pertumbuhan ekonomi maka akan mempengaruhi pembangunan manusianya. Pembangunan manusia harus memberikan dampak terhadap peningkatan kualita hidup manusia secara menyeluruh, baik menyangkut pemenuhan kebutuhan fisik maupun kebutuhan non fisik baik dari aspek kesehatan, pendidikan, maupun aspek ekonomi.Pembangunan manusia yang dimaksud dalam IPM berbeda dengan pengembangan sumber daya manusia yang biasanya dimaksudkan dalam teori ekonomi.Sumber daya manusia menunjuk pada manusia sebagai salah satu faktor produksi, yaitu sebagai tenaga kerja yang produktivitasnya harus ditingkatkan. Dalam hal ini manusia hanya sebagai alat (input) untuk mencapai tujuan yaitu peningkatan output barang dan jasa. Sedangkan manusia di dalam IPM lebih diartikan sebagai tujuan pembangunan yang berorientasi akhirnya pada peningkatan kesejahteraan manusia (Gevisioner, 2004 dalam Christy dan Adi, 2009).Salah satu ukuran IPM adalah besarnya pendapatan nasional yang digunakan untuk belanja pendidikan (Kuncoro, 2004).Untuk meningkatkan IPM khususnya dalam bidang pendidikan, caranya dengan memberantas buta aksara. Hal ini akan menjadikan 
masyarakat menjadi melek aksara. Untuk menjamin tercapainya tujuan pembangunan manusia terdapat empat hal pokok yang perlu diperhatikan, yaitu produktifitas, pemerataan, kesinambungan, dan pemberdayaan.

Pada penganalisaan tidak langsung (indirect effect), pertumbuhan ekonomi daerah dapat digunakan untuk memediasi hubungan antara belanja modal dengan indeks pembangunan manusia (IPM), begitupun dalam hubungan antara belanja pegawai dengan indeks pembangunan manusia (IPM).Hal ini ditunjukkan nilai signifikansi kurang dari 5\%.Pertumbuhan ekonomi memediasi hubungan antara belanja modal dengan indeks pembangunan manusia (IPM), yang artinya belanja modal dapat mempengaruhi secara langsung maupun tidak langsung terhadap indeks pembangunan (IPM).Pertumbuhan ekonomi memediasi hubungan antara belanja pegawai dengan indeks pembangunan manusia (IPM), yang artinya belanja pegawai dapat mempengaruhi secara langsung maupun tidak langsung terhadap indeks pembangunan manusia (IPM).

\section{Kesimpulan}

Berdasarkan hasil penelitian yang telah diuraikan dalam bab terdahulu, maka dapat ditarik kesimpulan sebagai berikut :

1. Belanja modal tidak berpengaruh positif dan tidak signifikan terhadap pertumbuhan ekonomi daerah di Kabupaten Hulu Sungai Tengah tahun 2010 - 2016.

2. Belanja pegawai tidak berpengaruh positif dan tidak signifikan terhadap pertumbuhan ekonomi daerah di Kabupaten Hulu Sungai Tengah tahun 2010 - 2016.

3. Belanja modal berpengaruh negatif dan signifikan terhadap indeks pertumbuhan manusia (IPM) di Kabupaten Hulu Sungai Tengah tahun 2010 - 2016. Semakin tinggi belanja modal akanmenurunkan indeks pertumbuhan manusia (IPM).

4. Belanja pegawai berpengaruh positif dan signifikan terhadap indeks peertumbuhan manusia (IPM) di Kabupaten Hulu Sungai Tengah tahun 2010 - 2016.

5. Pertumbuhan ekonomi daerah berpengaruh positif dan signifikan terhadap indeks pertumbuhan manusia (IPM) di Kabupaten Hulu Sungai Tengah tahun 2010-2016.

\section{DAFTAR PUSTAKA}

Arikunto, Suharsimi. 1993. Prosedur Penelitian Suatu Pendekatan Praktek. Rineka Cipta Jakarta.

Bastian, Indra. 2006. Sistem Akuntansi Sektor Publik. Edisi 2. Salemba Empat:Jakarta.

Erlina, dkk. 2012. Pengelolaan dan Akuntansi Keuangan Daerah. USU Press:Medan.

Dessler, Gary, 1997. Manajemen Sumber Daya Manusia. Jilid I. Jakarta. Prenhallindo.

Halim, Abdul dan Abdullah, Syukriy. 2004. Pengaruh Dana Alokasi Umum dan Pendapatan Asli Daerah terhadap Belanja Pemda. Studi Kasus Kabupaten dan Kota di Jawa dan Bali. Jurnal Ekonomi STEI. No. 2/Tahun XIII/25.

Herlambang. Tedy, dkk, 2001. Ekonomi Makro. Teori, Analisis, dan Kebijakan. Jakarta. PT. Gramedia Pustaka Utama.

Kintamani, Ida. 2008. Analisis Indeks Pembangunan Manusia (Human Development Indekx). Jurnal pendidikan dan kebudayaan No. 072, Tahun ke-14 Mei 2008.

Kuncoro, Mudrajad. 2004. Otonomi dan Pembangunan Daerah, reformasi, Perencanaan, Strategi dan peluang. Yogyakarta. Erlangga.

Mardiasmo. 2002. Otonomi dan Manajemen Keuangan Daera. Yogyakarta: Penerbit ANDI.

Mahmudi, 2003. Manajemen Kinerja Sektor Publik Jakarta. Unit Penerbut dan Percetakan Akuntansi Manajemen Perusahaan YKPN.

Nazir, M. 2005. Metodologi Penelitian. Jakarta Ghalia Indonesia.

Nazir, Moh., Metode Penelitian, Jakarta: Ghalia Indonesia. 
Ujianto, Kuswandi \& Melania..2015. Pedoman Penulisan Tesis. Sekolah Tinggi Ilmu Ekonomi Pancasetia : Banjarmasin

Peraturan Direktorat Jendral Perbendaharaan Nomor PER-33/PB/2008 tentang Pedoman Penggunaan AKUN Pendapatan, Belanja Pegawai, Belanja Barang dan Belanja Modal.

Peraturan Menteri Dalam Negeri Nomor 22 Tahun 2011 tentang Pedoman penyusunan Anggaran Pendapatan dan Belanja Daerah Tahun Anggaran 2012.

Prasetya, Arik \& Kato, Masanori. 2011. The Effect of Financial and Non Financial Compensation to the Employee Performance. The 2rd International Research Symposium in Service Management. Yogyakarta, 26-30 July 2011, 382-391.

Ranis, Gustav \& Stewart, Frances. 2002. Economic Growt and Human Development in Latin America. Cepal Review 78. Desember 7-23.

Samuelson, Paul A. dan William D. Nordhaus, 2001. Macroeconomica. Seventeenth Edition. McGraw-Hill Higher Education.

Saragih, Juli Panglima. 2003. Desentralisasi Fiskal dan Keuangan Daerah dalam Otonomi. Jakarta Penerbit Ghalia Indonesia.

Sarwono, Jonathan. 2006. Metode Penelitian Kuantitatif dan Kualitatif. Yogyakarta: Graha Ilmu.

Siahaan, Safrudin. 2011. Membaca IPM sebagai Syarat Revolusi. Diakses di http://politik.kompasiana.com/2011/05/27/membaca-ipm-sebagai-syarat-revolusi/

Sharma, S. and Sharin, D., 1989. Organizational Climate, Job Satisfaction and Job Anxiety. Psychological Studies, Vol. 34, pp. 21 - 27. 